\title{
The Behavior of Brazilian Senators: Analyzing the Exchange of Votes inside the Fixed Committees during the $5^{\text {nd }}$ Legislature $^{*}$
}

\author{
Arnaldo Mauerberg Junior ${ }^{1}$ \\ Eduardo Strachman ${ }^{2}$ \\ Daniela Reami ${ }^{3}$
}

\begin{abstract}
Using the method of Social Networks Analysis, we'll try to see if politicians swap votes between them seeking support for their projects, to this end, we'll first map the behavior, activities and contacts of the Senators of the Brazilian Federative Republic within all the fixed committees which had some vote during the $52^{\text {nd }}$ Legislature, then we can see the most popular and central Senators to each committee. After this analysis we wish to answer the following question: did logrolling exist in the Brazilian Senate? Previously the empirical analysis and response to the problems posed, we'll present the necessary theoretical introduction understood by reviewing the literature on relevant subjects, whether they are purely theoretical with respect to the exchange of support, or analytical about the Brazilian political system.
\end{abstract}

Key-words: Logrolling; Legislative Activity; Brazilian Senate; Social Networks Analysis

JEL: $\mathrm{H}_{3}, \mathrm{H}_{7}, \mathrm{H}_{7}, \mathrm{H} 83$

\footnotetext{
* The authors thank the comments and suggestions of Professors Paulo Furquim de Azevedo and Cláudio César de Paiva.

1 Pesquisador do Centro de Estudos em Política e Economia do Setor Público da Fundação Getúlio Vargas (CEPESP/FGV). Doutorando em Administração Pública e Governo pela FGV/EAESP com estágio doutoral no Massachusetts Institute of Technology (MIT) onde atua como Fellow Researcher no Departamento de Ciência Política. Também é Mestre em Economia pela UNESP/FCLAr. E-mail: amauer@mit.edu

2 Professor Adjunto do Departamento de Economia da UNESP/FCLAr. Doutor em Economia IE/UNICAMP. E-mail: edstrach@fclar.unesp.br

3 Graduada em Ciências Econômicas pela UNESP/FCLAr. E-mail: daniela_reami@hotmail.com
} 


\title{
O Comportamento dos Senadores Brasileiros: Analisando a Troca de Votos nas Comissões Fixas durante a $5^{a}$ Legislatura
}

\begin{abstract}
Resumo: Utilizando a metodologia de Análise de Redes Sociais, intentamos analisar se os políticos brasileiros trocam votos na aprovação de projetos de lei em busca de apoio futuro. Para tanto, buscamos primeiramente mapear o comportamento, a atuação e os contatos dos Senadores da República Federativa do Brasil dentro das comissões fixas que tiveram qualquer movimentação durante a $52^{a}$ Legislatura, poderemos então ver quais são os Senadores mais atuantes e centrais em cada comissão. Após este mapeamento procuramos criar meios de análise para responder a questão teórica da existência ou não do logrolling no Senado Brasileiro. Anteriormente a análise empírica e resposta aos problemas propostos, apresentaremos a devida introdução teórica compreendida por uma revisão de literatura sobre os temas pertinentes, sejam eles puramente teóricos a respeito da troca de apoio, sejam eles analíticos a respeito do sistema político brasileiro.
\end{abstract}

Palavras-chave: Troca de Votos; Atividade Legislativa; Senado Brasileiro; Análise de Redes Sociais.

JEL: $\mathrm{H}_{3}, \mathrm{H} 7, \mathrm{H} 77, \mathrm{H} 83$

\section{Introduction}

The question regarding government intervention or the maintenance of a totally free system has divided theorists long ago. According to Hardin (1997), there are three reasons for the state existence: the supply of public goods, the coordination between agents and the maintenance of a stable evolution. The first reason has in its defenders authors like Adam Smith and David Hume, while the second gets support in Thomas Hobbes and others. Mueller (1997) says that the rising of government occurs in a way to fall the transactions costs in a society with many agents. Ostrom and Walker (1997) show institutions that are between the full liberalism and the total state, which arise to solve problems of collective action.

As a famous economic example, Keynesian theory shows a model where the state is incorporated in a more explicit way to solve crisis and stabilize the economy, acting for this in a countercyclical way. So, the state would act in a similar way like the one proposed by Hardin (1997), Mueller (1997), Ostrom and Walker (1997), and others.

Thinking the agents inside the government as the agents in the conventional 
economic theory, this work seeks to analyze the logrolling. We will seek to provide the means to prove whether or not this practice can be seen among Brazilian Senators in the period of the $52^{\text {nd }}$ Legislature. For this we will map parliamentary activity within the fixed committees of the Senate regarding the issuance of opinions and judgment of bills.

Besides this introduction, the article has more two sections and a conclusion. In the first section, we will carry out the theoretical approach for the topic, presenting the reader with the concept of exchanging votes, how it can be done, some characteristics that make it easily practiced and a brief discussion of the Brazilian political game. The second section presents the empirical tests in an attempt to note down or not, the presence of exchanging votes within the fixed commissions of the Brazilian Senate. Our hypothesis is that we can observe exchanges between Senators.

\section{Theoretical Approach}

Apparently, the exchange of votes can be sentenced by most people, but there are cases where it appears as beneficial, although there are others in which it shows itself deleterious to society as a whole. Consider the following example:

TABLE 1. BASIC LOGROLLING EXAMPLE

\begin{tabular}{c|c|c}
\hline Voters & Project X & Project $\mathrm{Y}$ \\
\hline A & 7 & -3 \\
B & -3 & -3 \\
C & -3 & 7 \\
\hline
\end{tabular}

Prepared by the authors

From table 1 we can see three voters (A, B and C) and two projects (X and Y). The numbers 7 and -3 represent the generated utility on people if the project is approved, or, it's the benefit created to the voter when some project wins. In a simple majority rule, none project is accepted, because, if we look to the project $\mathrm{X}, \mathrm{B}$ and $\mathrm{C}$ will vote against and, looking to project $\mathrm{Y}, \mathrm{A}$ and $\mathrm{B}$ will have that behavior, in both cases we'll have two votes against and one for, so, the total utility for this society with three persons will be zero. But if A and $\mathrm{C}$ agreed to exchange their votes, $\mathrm{C}$ voting for the $\mathrm{X}$ bill since $\mathrm{A}$ vote for the $\mathrm{Y}$ bill, both projects will be accepted and the total utility will be equal 2 . In this case, logrolling can create a benefit to the society. But, if instead of using -3 in the example, we use -4 , to all negative numbers, logrolling would create an aggregate utility of -2 , being a bad deal in an aggregated way.

So, we can conclude that logrolling introduces a new feature to the voting process: while majority rule considers the preferences in an ordinal way, 
logrolling allows us to see the preferences and their intensity cardinally. According to Mueller (2009), the support exchange on projects exists because the preferences are not equal between the agents. Thus, the exchange prevents a minority very desirous of a given project to be bullied by a majority apparently indifferent to the same project. From the foregoing, we conclude that, to the exchange be beneficial, the rise in utility of the minority must be greater than the utility loss suffered by others involved in the transaction. In the previous example, the gain of the minority was 7 , while the loss of the majority was equal to 6, thus generating an exchange beneficial, with final result of +1 .

Carruba and Volden (2000) say that logrolling is easier when: there are few politicians, projects bring more benefits than costs, future has a big value, the reelection chance is very high, the coalitions are easy to be created and the voting rules are less inclusive. To Buchanan and Tullock (1990 [1962]), logrolling is difficult only in some situations, like referendums, because nobody knows when it will be the next event where the exchange can be concluded. Another source of problems to referendums is about the size of the population, in this scenario, each person is a very little part of the voters' universe.

Let's now consider the question of intransitivity in the polls, assuming that there are three alternatives, A, B and C, and three agents, Charles, John and Mary:

TABLE 2. INDIVIDUAL TRANSITIVITY AND COLLECTIVE INTRANSITIVITY

\begin{tabular}{c|c|c}
\hline A e B & B e C & A e C \\
\hline A - 2 votes (Charles e John) & B - 2 votes (Charles e Mary) & C - 2 votes (John e Mary) \\
B - 1 vote (Mary) & C - 1 vote (John) & A - 1 vote (Charles) \\
\hline
\end{tabular}

Fonte: Wieting Jr. (1966)

Analyzing agents' individual transitivity:

\begin{tabular}{c|c|c}
\hline Charles & John & Mary \\
\hline A is preferably than B & C is preferably than A & B is preferably than C \\
B is preferably than C & A is preferably than B & C is preferably than A \\
A is preferably than C & C is preferably than B & B is preferably than A \\
\hline
\end{tabular}

So, to all agents individually, transitivity is ok. But, from table 2 we can see that in an aggregate way, or, to all agents together transitivity does not exist. From the outcome vote board we have:
A is preferably than $B$
$\mathrm{B}$ is preferably than $\mathrm{C}$
$\mathrm{C}$ is preferably than $\mathrm{A}$ 
This clearly shows intransitivity, or cyclical behavior. So, individual transitivity doesn't guarantee aggregate transitivity. According to Bernholz (1973), logrolling is possible only when social preferences are transitive, and at the same time, intransitive social preferences make logrolling impossible. Stratman (1997) says that the costs of an approved project should be paid by everyone, not only by the beneficiaries of it, creating in the latest the feeling that the project is cheaper than it really is. This creates an increase in the supply of these projects, generating a transfer of resources from the loser minority to the winner majority (coalition).

Let's see another approach to show the benefits and harms of logrolling regarding the stability and instability of coalitions. Since the previous example is a little confuse, because we never can get the social preference, and even if we could, we never know if the agents are telling the truth in a way to building a preference scale, according to Stratman (1997), if the coalitions are politically unstable the benefits of logrolling wouldn't appear.

This point starts another debate about exchanging votes: those who believe in instability pay attention to the dangers of logrolling, while proponents argue that the stability of logrolling generates benefits, in aggregate, because the agents are afraid to break a coalition, knowing that in the future they will be penalized if acting so treacherous.

Tullock (1981) shows a theoretical model using payoffs to say that people that are in same conditions don't have interest in seek advantages positions if they can be betrayed in the future. So, if a coalition is formed in which all the agents have the same payoff in the agreement, there'll be no reason for a treacherous behavior. Coleman (1967) like Tullock (1981) advocates stability based it in the agents' credibility. Koford (1982) also comes out in defense of stability, minimizing the complexity of the political system, supposing that exchanges are performed only between the party leaders, in this way, with a small number of interactions, control and prediction of the behavior of allies become easier.

Bernholz (1978) is another author who argues in favor of stability presenting a mathematical model to show that, within interest groups well-founded, with long existence, coalitions formed with the intention of practicing explicit logrolling are stable over time.

Contextualizing the issue in Brazilian terms, there are works on logrolling in Brazil, such as Pereira and Mueller (2002), which state that the executive reward with projects individual legislators who vote in favor of the budget it proposed while Congressmen make use of this money for individual projects to be re-elected at all costs. However, Figueiredo and Limongi (2002) disagree with this assertion and say that in Brazil, the preferences of politicians are not homogeneous in the quest for reelection, as it is in the U.S., where politicians seek close ties with their constituencies, to ensure a new mandate. 
Pereira and Mueller (2003) countered by saying that, in Brazil, there is, on the one hand, a weak link party, in the electoral arena, in which candidates seek his constituency alone and not rely heavily on the party, while on the other hand, in the legislative arena, the dependence to the political party is very strong, for he needs the help of the latter to obtain funds with the Executive in order to achieve their individual projects. From this fact, and contrary to what was proposed by Figueiredo and Limongi (2002), Pereira and Mueller (2003) state, based on empirical tests, that the greater the number of individual amendments executed, the greater the chance of re-election, concluding that parties in the electoral arena are weak, and strong in the legislative, thanks to logrolling between the executive and party leaders. About the stability of coalitions internally, Wolf (2008) shows that, in the Brazilian House of Representatives, during the $52^{\text {nd }}$ Legislature (2003-2006), the alliance between politicians can be considered stable.

It is not our main objective, we will not make an extensive analysis about logrolling and its relation with majority rule problems, but if the reader want to learn more about the question you can find some good works on Buchanan and Tullock (1990 [1962]), Tideman (1997), Enelow (1997), Peyton Young (1997), Schofield (1997), Mueller (2009), Shepsle and Weingast(1981) and the theorems of May, Condorcet, Black and Plott.

\section{Empirical Analysis ${ }^{1}$}

Reviewed the literature, we will make now the empirical analysis of the data, with the aim of mapping the network of contacts of Brazilian Senators in the $52^{\text {nd }}$ Legislature, within the fixed commissions of the Senate. Our database consists of the opinions offered by the rapporteur to a given bill introduced by another Senator, in a permanent committee of the Senate. According to the Article 126 of the laws of the Senate: the appointment of a rapporteur, independent of matter and committee meeting will follow the party representations or proportion of the parliamentary groups in that area; will alternate between its members and far will be in two business days after the receipt of the project. The article 133 of the same book says that: every opinion shall be conclusive in its analysis (Brazil, 2007), then, based on this information, we know that the choice of a rapporteur follows the partisan criteria and if a vote is favorable or unfavorable.

The material of this paper is the opinion of bills, more precisely, the settlement of opinions given by one Senator to another in bills of the latter agent - the analysis of settlement opinions is used because we cannot consider a Senator who received 5 favorable opinions of a colleague, for example, successful in his projects, if he received 10 negative opinions of the same colleague in the same period. In this hypothetical example, the Senator concerned would have 
a settlement of -5, i.e., computing his successes and failures, the agent had a bad result, on average, being this relationship described as dotted lines on the graph with value -5 . So, in the Social Network Analysis ${ }^{2}$ and based on visual observations obtained from the graphs generated, a favorable settlement of Senator A to bills introduced by Senator B is represented by an arrow filled, with its origin in A and target in B. If the settlement is negative (more negative opinions received than that positive ones) the relationship is represented, as already said, by a dotted arrow with origin in A and destination in B. That is, the lines in question could become thicker according to the value of the settlement: they will be darker and thicker in direct relation to the size of the settlement. Another concept is the settlement of some Senator connections with all his colleagues: if an agent receives positive settlement of 4 colleagues and negatives of 3 , he has a positive settlement of links equal to 1 , and we use this concept to measure his popularity in committee - called indegree.

Besides the interaction graphs, the methodology employed subsidized us with several indexes that will be analyzed whenever deemed necessary. It must be said that only the permanent committees of the Senate will be analyzed, because the mixed ones (Senate and House of Representatives) and the temporaries are not used to propose bills and the committees of inquiry also don't have the characteristics of the study, primarily serving as legislative investigation. The commissions analyzed will be: Economic Affairs Committee (CAE) ${ }^{3}$, Social Affairs Committee (CAS), Committee of Constitution, Justice and Citizenship (CCJ), Committee of Education, Culture and Sport (CE), Committee on Environment, Consumer Protection and Surveillance and Control (CMA), Commission on Human Rights and Legislation (CDH); Committee on Foreign Relations and National Defense (CRE), Committee of Services on Infrastructure (CI), Regional Development and Tourism Commission (CDR) ${ }^{4}$. The period of analysis is, once again, the $52^{\text {nd }}$ Legislature, which starts in 2003 January the $1^{\text {st }}$, and ends in 2006 December the $31^{\text {st }}$. Finally, we will conduct an intercommittee analysis, in order to observe if exist a more complex support characterized as follows: The agent A provides support to the agent B in commission $\mathrm{X}$, since the agent B offers its support to agent $\mathrm{A}$ in the commission $\mathrm{Y}$.

There's also a comment about the period of office of a Senator be eight years and the period of analysis be only four: this is because the election for the office is done to interleave the candidates with the three state representatives not being chosen only at the same time, so if we use a period of analysis of eight years, we assume the risk of look at a Senator for eight years and four Senators for four years each.

3 All the acronyms are regarding the names of the committees in Portuguese.

4 The Commission of Agriculture and Agrarian Reform and the Committee on Science, Technology, Innovation, Communication and Computing will not be analyzed because, during the four years, none opinion was issued on those centers of parliamentary discussion. 
We intend to analyze the performance of the Senators within each permanent commission, and also, in an intercommittee view, identifying its performance and interaction with parliamentary colleagues, we'll also try to identify the most active Senators and the characteristics of the connections between these agents (general purpose). We further aim to determine whether the proposition of the existence of logrolling is valid for the selected data (specific objective). At the end, we intend to answer the following question: did logrolling exist inside fixed commissions of the Brazilian Senate, during the period of the $52^{\text {nd }}$ Legislature?

Like every model, ours also has its limitations. We know that the political process is extremely complex, with links between different types of agents belonging to the three spheres of power, and such links do not always focus on politics. In addition, a support offered in this term should not necessarily be reciprocated in the same period temporally but it could in future legislatures. However, the large number of ramifications presented by the Brazilian political process, lead us to draw a sharp boundary to our analysis, we observed the behavior of Senators only within fixed commissions of the Brazilian Senate for the period indicated. We believe that the methodology of social network analysis is best suited for the study of the recent past, because we assume that inferences about the future behavior of the agents are difficult to conclusion, after all we handle data with high volatility, which vary according to the political atmosphere of the country.

\subsection{Economic Affairs Committee (CAE)}

The first committee to be analyzed is the Economic Affairs Committee. The figure below shows the settlement of opinion in the Commission.

The density of the committee as a whole is equal to $0.0212^{5}$, this is, agents do not interact strongly with each other because of 100 possible connections only 2.12 in fact exist. Note that a network of maximum density in a high-traffic commission is absolutely unlikely, because of the large number of projects that are presented. It would be unlikely that all Senators interact with each other. 
FIGURE 1. CAE SETTLEMENT OF OPINIONS

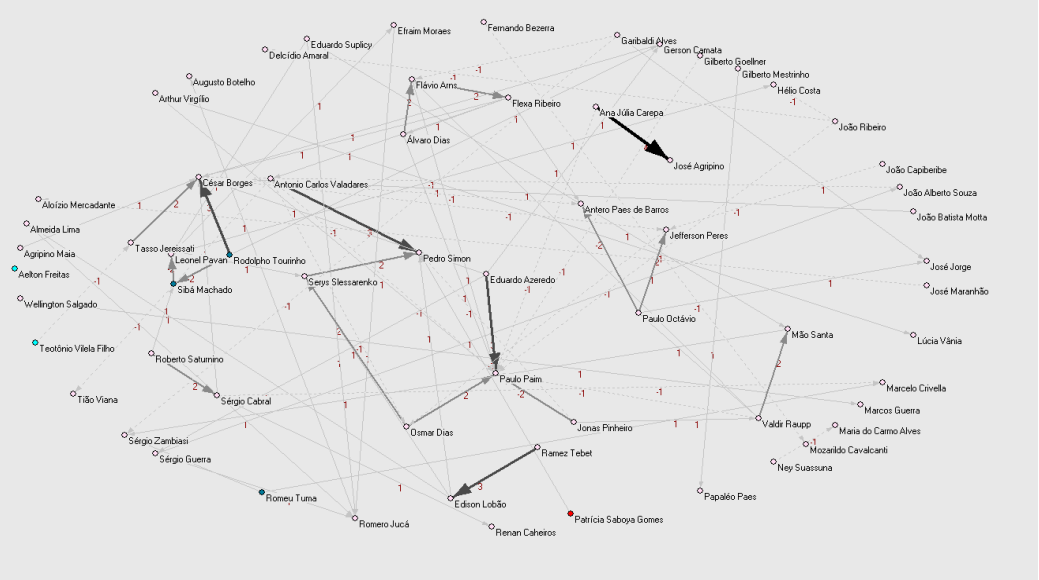

Developed by the authors, from Senate data.

We find in the network 83 connections between 63 different Senators. Each Senator interacts on average with 2.63 other Senators, i.e., that network is not concentrated, which is evidenced by the low degree of centralization index (0.1393).

The main actors being transmitters or receivers of opinion are the Senators César Borges (PR-BA) and Paulo Paim (PT-RS), with eleven links in all. Considering agents as emitters of opinions, the outdegree, Valdir Raupp (PMDB-RO), Flexa Ribeiro (PSDB-PA), Antonio Carlos Valadares (PSB-UP) and Eduardo Azeredo (PSDB-MG) appear at the top of the list, each one of them giving opinions to four different colleagues.

Searching a measure of popularity (the number of colleagues who sent their opinions) through indegree, Paulo Paim and César Borges appear at the first and second on opinions received, eleven and nine colleagues respectively. However, the first has six negative connections (dashed arrows) and five positive (filled arrows), giving a settlement equal to -1 , which can lead to some misunderstanding about his popularity in general.

About the centrality measure, individually we observe that the points with higher values are once again Paim and César Borges (PR-BA). The more intense relationship is between Ana Julia Carepa (PT-PA) and José Agripino Maia (DEM-RN), which shows that the Senator offered four positive opinions to the representative of Rio Grande do Norte. The fact that these Senators come from ideological party tendencies usually considered opposites leads us to consider this fact as evidence of a weak exchange of support between them ${ }^{6}$. 
Like one of the objectives of this study is to test the proposition of logrolling, we seek a measure that shows reciprocal trades sharply, or, exchanges actually performed. Assuming the example of the settlement from A to B is +5 , we have to get the settlement from B to A, assuming B issued positive opinions for seven projects authored by A and three against, then we would have a positive settlement of +4 . In this case, to compute the exchange of votes between agents $\mathrm{A}$ and $\mathrm{B}$, and the settlement of $\mathrm{A} \rightarrow \mathrm{B}$ equal to +5 and the settlement $\mathrm{B}$ $\rightarrow$ A equals +4 , we can then compute exchanging votes on bills to the pair in question the value +4 . Thus, for obtaining the settlement of trade, we must consider the value that both relations have in common ${ }^{7}$. This is our parameter to identify strong evidence of trade between the Senators. However, other trends can be observed, which we classify as weak evidence of support or exchange, for example, the unilateral relationship already identified between Carepa and Agripino Maia, which leads us to believe that the strong support offered here could be reciprocated in another field or time. Using this method, we can conclude that in the Economic Affairs Committee there were no sharp exchanges between the parliamentary, but not forgetting the evidence found in the relations between Agripino Maia and Carepa.

\subsection{Social Affairs Committee (CAS)}

For the Social Affairs Committee, applying the calculation to obtain the settlement of opinions, we arrive at figure 2. The average number of connections reaches 2.57 average links of each Senator to peers. Among the 56 senators present in the network, there are 72 connections. The most significant connection is between Geraldo Mesquita Junior (PMDB-AC) and Paulo Paim (PT-RS), with the first offering four positive opinions to the second. In fact, as the positive link between Ana Julia Carepa (PT-PA) and José Agripino Maia (DEM-RN) at CAE led us to the assumption of weak evidence in support of trade, this link between the Senators of Acre and Rio Grande do Sul also leads us to believe that there is a support that will be repaid in another political field or timeline.

At the Commission on Social Affairs, Paulo Paim has relationship (positive and negative) with 22 other colleagues, followed by Marcelo Crivella (PRB-RJ), who has a degree 9. As a consequence, the central point in the network is represented by this gaucho PT Senator. The second and third places, in the aspect of centrality, are occupied by Mão Santa (PSC-PI) and Crivella, while Reginaldo Duarte (PSDB-CE) and Euripides Camargo (PT-DF) have a measure of centrality of zero. Like an element acting as a "bridge" among his colleagues, appears once again Paulo Paim. 
FIGURE 2. CAS SETTLEMENT OF OPINIONS

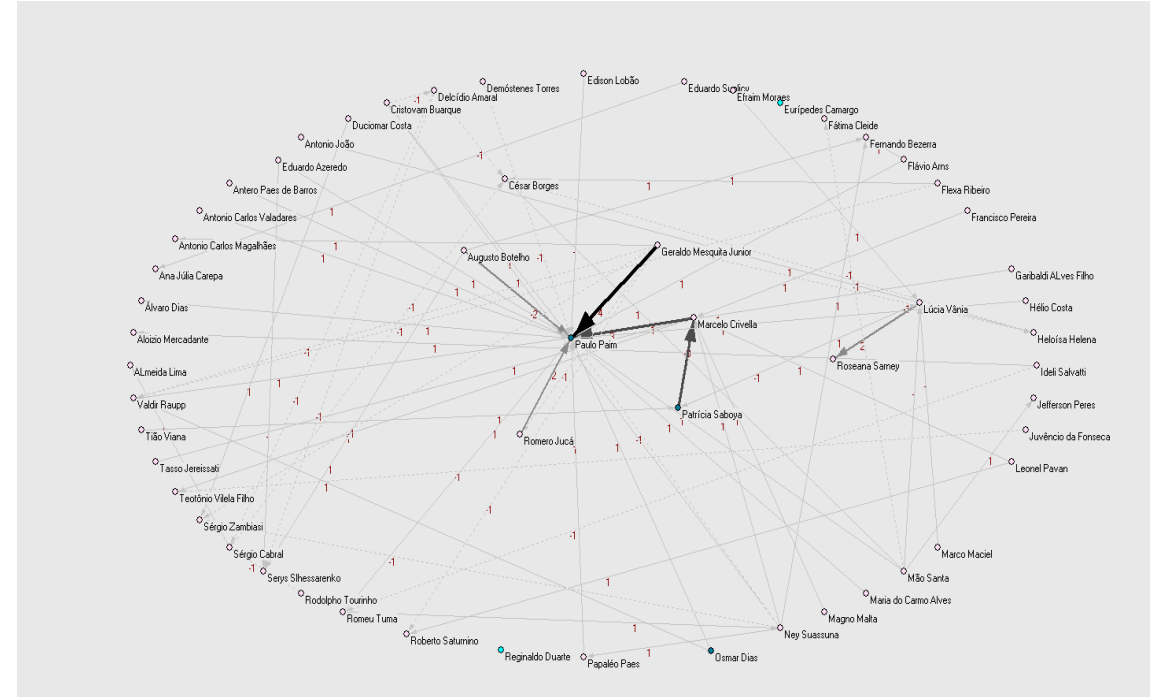

Developed by the authors, from Senate data.

Testing the hypothesis of logrolling, we see two reciprocities in the network. The first is observed between Marcelo Crivella and Paulo Paim: the first issued a positive opinions settlement of three to the second ${ }^{8}$, receiving in return only one, i.e., the observed exchange between agents is equal to one. The second reciprocity occurs between Patricia Saboya (PDT-EC) and Lúcia Vânia (PSDB-GO): the first issued a positive settlement of magnitude 1 for the second, getting a settlement of this same magnitude but negative, which does not allow us to consider it like a logrolling relation. Finally the Senator most representative of this commission is, once again, Paim. As a conclusion of the test for the logrolling, we have no strong evidence that lead us to believe that this is done in this committee, since only a small exchange of intensity was observed, but not forgetting the evidence found in the relations between Mesquita Junior and Paulo Paim.

\subsection{Committee of Constitution, Justiceand Citizenship (CCJ)}

Regarding CCJ, we can see that this committee is the one which has the highest number of bills proposed and analyzed in the period.

Generally speaking the network above has low density, i.e., despite being the committee with the highest number of feedbacks or opinions sent, they are send by a small group of Senators inside the committee. Each agent is connected on average to 1.91 colleagues. The relationship more intense is up to 
Demóstenes Torres (DEM-GO) and Pedro Simon (PMDB-RS), parliamentary with distinct regions and ideology, which leads us to assert that this is a weak evidence of some kind of parliamentary support.

\section{FIGURE 3. CCJ SETTLEMENT OF OPINIONS}

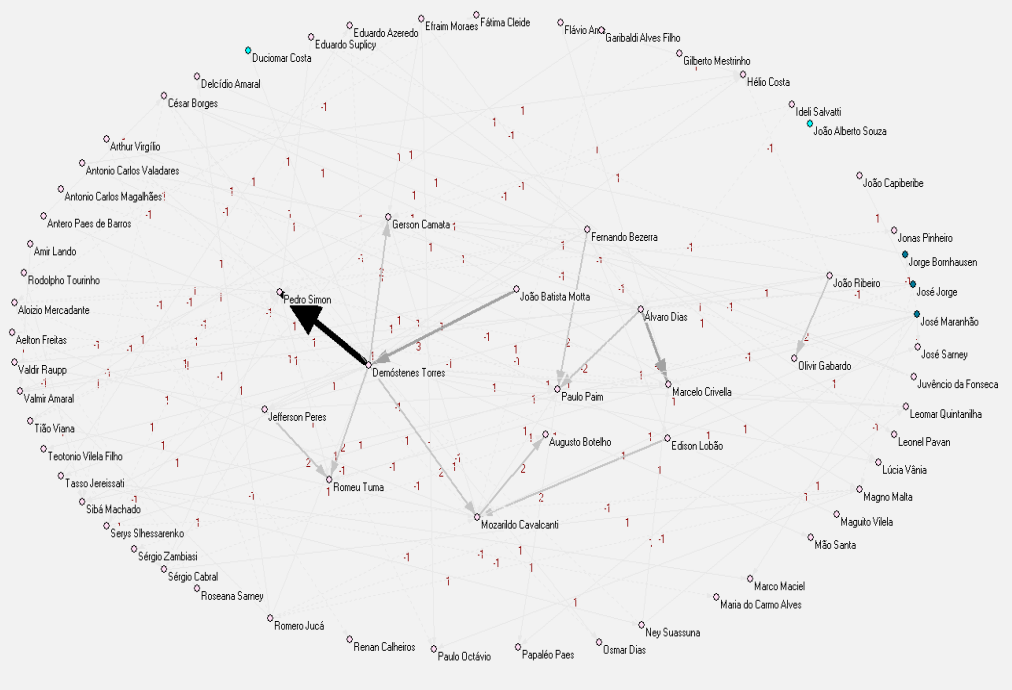

Developed by the authors, from Senate data.

The analysies shows that Paulo Paim (PT-RS) received favorable opinions from nine peers and only three colleagues offered him just contrary opinions. So, his settlement of links is equal to six. Pedro Simon received favorable opinions from six Senators, and negative feedbacks to his bills from seven agents, having a settlement of links equal to -1 . Demóstenes Torres, has an indegree of 3. The most popular Senator inside the committee is, again, Paulo Paim. But now, he doesn't have centrality and betweeness characteristics, these are characteristics of Simon and Torres respectively.

Testing the logrolling hypothesis, we find, like in CAS, only two reciprocity between the vertices. The first one belongs to Romeu Tuma (PTB-SP) and Pedro Simon. The former sent a settlement of +1 to the latter while Simon did the same. The second relation regards to Jefferson Peres (PDT-AM) and Marcelo Crivella (PRB-RJ): the first sent a settlement of +1 to the second receiving from him a settlement of -1 . As a conclusion of the test of logrolling, we have no strong evidence that this is done in this committee, since only a small intensity exchange was observed. We also can see that the most representative Senators in this commission were Demóstenes Torres, Pedro Simon and Paulo Paim. 


\subsection{Committee of Education, Culture and Sport (CE)}

The Committee of Education, Culture and Sport has a small number of bills analyzed in the period, the net regarding the settlement of opinions gave by the rapporteurs follows:

\section{FIGURE 4. CE SETTLEMENT OF OPINIONS}

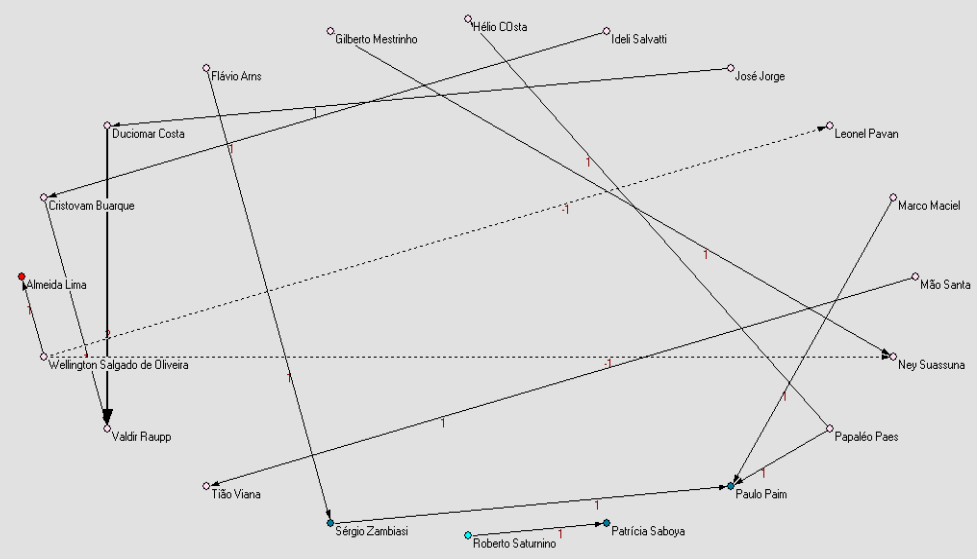

Developed by the authors, from Senate data.

Observing figure 4, we can infer that agents with greater settlement of connections, sending or receiving opinions are senators Paulo Paim (PT-RS) and Wellington Salgado (PMDB-MG), with a degree equal to three. This commission also found no evidence of logrolling.

\subsection{Minor Movement Committees}

Here we'll show the settlement of opinions in the committees with a small number of bills judged in the period. Unfortunately, because this small number, Social Network Analysis measures cannot be computed, and we'll concentrate only in the visual observation of the nets.

During the four years of the $52^{\text {nd }}$ Legislature only one bill was analyzed in this committee, with a negative opinion gave to Serys Slhessarenko from César Borges. 
FIGURE 5. REGIONAL DEVELOPMENT AND TOURISM COMMISSION (CDR) SETTLEMENT OF OPINIONS

Developed by the authors, from Senate data.

FIGURE 6. COMMISSION ON HUMAN RIGHTS AND LEGISLATION (CDH) SETTLEMENT OF OPINIONS

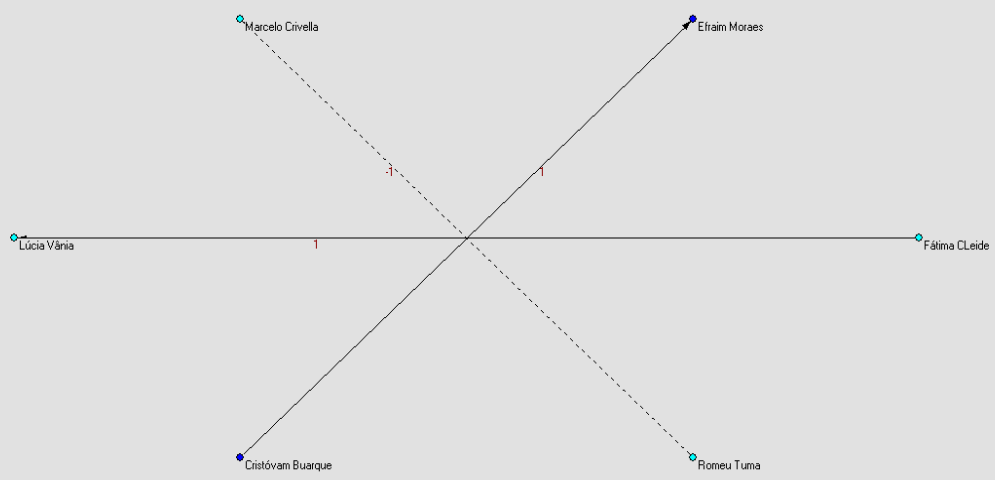

Developed by the authors, from Senate data.

An analysis of this net shows that only three opinions were given in the period of analysis. 
FIGURE 7. COMMITTEE ON ENVIRONMENT, CONSUMER PROTECTION AND SURVEILLANCE AND CONTROL (CMA) SETTLEMENT OF OPINIONS

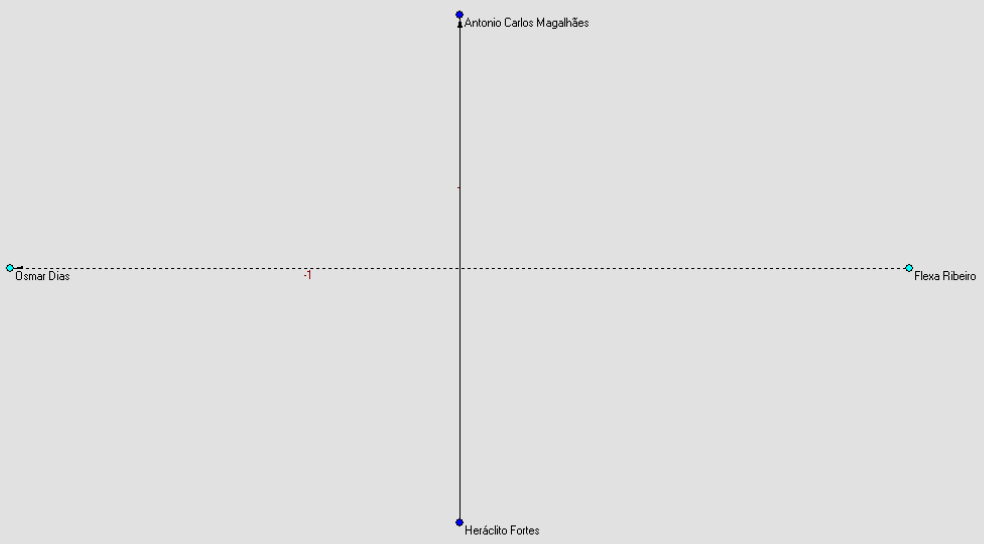

Developed by the authors, from Senate data.

Just four Senators acted as author or rapporteurs in this committee. A very low movement committee.

FIGURE 8. COMMITTEE ON FOREIGN RELATIONS AND NATIONAL DEFENSE (CRE) SETTLEMENT OF OPINIONS

Developed by the authors, from Senate data. 
FIGURE 9. COMMITTEE OF SERVICES ON INFRASTRUCTURE

(CI) SETTLEMENT OF OPINIONS

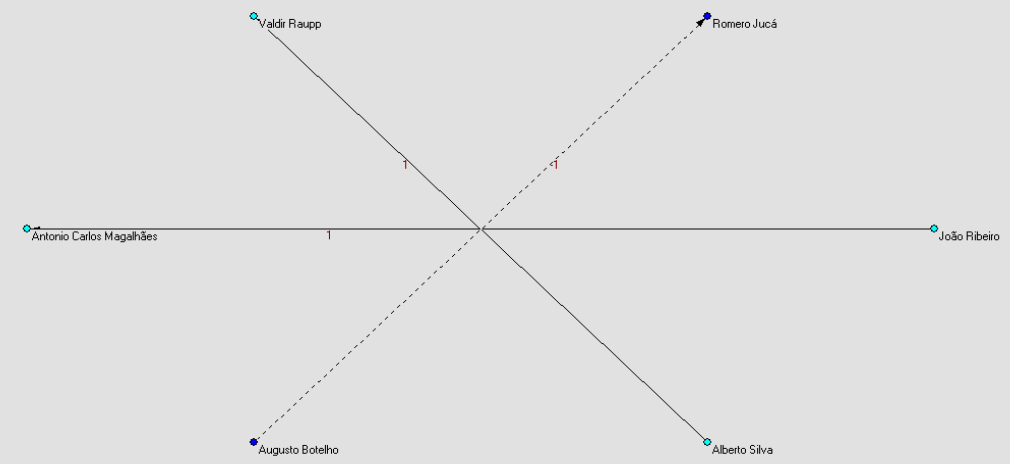

Developed by the authors, from Senate data.

Like the others minor movement committees, these last two showed in sum a small index of parliamentary activity.

We still can see that the Commission of Agriculture and Agrarian Reform (CRA), and the Committee on Science, Technology, Innovation, Communication and Computing (CCT) had no bills analyzed in the period, which shows a very less intense parliamentary activity in those fields of interests.

\subsection{Intercommitte analysis}

As in the analysis of separate committees we couldn't find strong evidence that the logrolling was practiced in the Brazilian Senate, before we reject our hypothesis (that the logrolling exists within the proposed limits) we will hold a final test to see if the Senators interact between commissions, practicing a kind of support less visible characterized by the following conduct: a Senator offers support to a colleague in a given committee, since this fellow return the vote in another committee. To this we add the settlement of opinions on all committees already analyzed. 
FIGURE 10. INTERCOMMITTEE SETTLEMENT OF OPINIONS

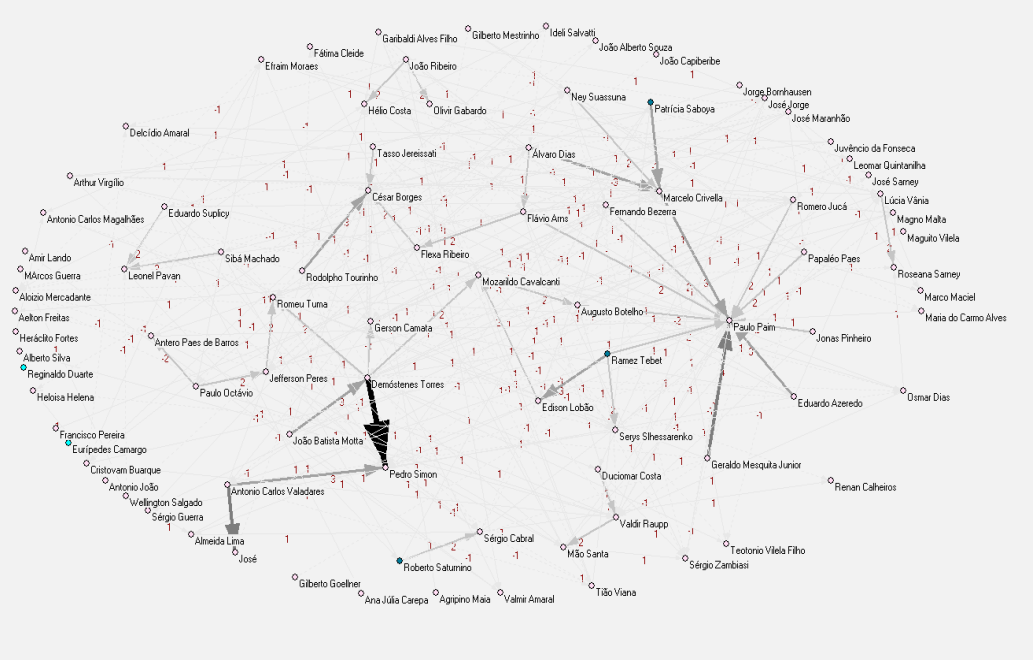

Developed by the authors, from Senate data.

The figure above represents the settlement of opinions, summed on all committees that had movement in the period analyzed. In a pooled analysis, only $3.9 \%$ of the possible relations are actually executed: each Senator has on average 6.86 connections (positive or negative) with other colleagues. Senators with more connections are Paulo Paim (PT-RS), César Borges (PR-BA) and Demóstenes Torres (DEM-GO) with 32, 22 and 21 links, overall, respectively, disregarding their direction, intensity and support position. From the graph we also extract the full support exchange between agents, using the same methodology employed in the analysis of separate committees, the interaction in both senses of the total network is given by the following table:

From Table 3 we observe that only the relations made by the letters C, D and $\mathrm{E}$ may be considered exchanging votes among parliamentarians. Note that the few exchanges observed previously in some two committees do not necessarily remain, imagine that in a given commission an agent offered a settlement of +3 to a colleague, getting back a settlement of +2 , bringing the trade settlement equal to +2 in the committee, while in another committee the values of the settlement between the agents are identical, but with signs reversed, i.e., $-3,-2$ and -2 : the commissions aggregating settlement of trade between these agents, in an intercommittee analysis, would become zero. 
TABLE 3. BIDIRECTIONAL INTERCOMMITTEE RELATIONS

\begin{tabular}{|c|c|c|c|c|}
\hline Relation & Rapporteur & Author & $\begin{array}{c}\text { Settlement of reports } \\
\text { sent favorable }(+) \text { or } \\
\text { against }(-)\end{array}$ & $\begin{array}{l}\text { Exchange } \\
\text { settlement }\end{array}$ \\
\hline \multirow{2}{*}{ A } & Jefferson Peres & Marcelo Crivella & +1 & \multirow{2}{*}{$\mathrm{O}$} \\
\hline & Marcelo Crivella & Jefferson Peres & -1 & \\
\hline \multirow{2}{*}{ B } & Lúcia Vânia & Patricia Saboya & -1 & \multirow{2}{*}{$\mathrm{O}$} \\
\hline & Patricia Saboya & Lúcia Vânia & +1 & \\
\hline \multirow{2}{*}{$\mathrm{C}$} & Marcelo Crivella & Paulo Paim & +3 & \multirow{2}{*}{+1} \\
\hline & Paulo Paim & Marcelo Crivella & +1 & \\
\hline \multirow{2}{*}{ D } & Pedro Simon & Romeu Tuma & +1 & \multirow{2}{*}{+1} \\
\hline & Romeu Tuma & Pedro Simon & +1 & \\
\hline \multirow{2}{*}{$\mathrm{E}$} & Paulo Paim & Papaléo Paes & +1 & \multirow{2}{*}{+1} \\
\hline & Papaléo Paes & Paulo Paim & +2 & \\
\hline \multirow{2}{*}{$\mathrm{F}$} & Paulo Paim & Valdir Raupp & +1 & \multirow{2}{*}{$\mathrm{O}$} \\
\hline & Valdir Raupp & Paulo Paim & -1 & \\
\hline \multirow{2}{*}{ G } & Paulo Paim & Ant. Valadares & +1 & \multirow{2}{*}{$\mathrm{O}$} \\
\hline & Ant. Valadares & Paulo Paim & -1 & \\
\hline \multirow{2}{*}{$\mathrm{H}$} & Romero Jucá & Augusto Botelho & +1 & \multirow{2}{*}{ O } \\
\hline & Augusto Botelho & Romero Jucá & -1 & \\
\hline
\end{tabular}

Developed by the authors, from Senate data.

We also note that the interaction between the Senators in exchange for support intercommittee is poor, with very few clearest exchanges within a large universe of data, refuting the existence of logrolling in fixed commissions of the Senate, whether analyzed independently or jointly.

\section{Conclusions}

In this article we wanted to study the exchange of votes between politicians. Making use of the social network analysis, we observed that in the Economic Affairs Committee, the agents did not interact strongly with each other, with only $\mathbf{2 . 1 2} \%$ of all possible connections done. We also note that the Senator most popular - who received a positive settlement of opinions, from a largest number of colleagues - was César Borges (PR-BA).

In the Social Affairs Committee, Paulo Paim (PT-RS) figured as the agent who had connections with the largest number of colleagues (22 in all). In this committee, we realized that the more "productive" agents were Paim and 
Marcelo Crivella (PRB-RJ). There was also a reciprocity in the relationship between Patricia Saboya (PDT-EC) and Lúcia Vânia (PSDB-GO), although this reciprocity cannot be considered as evidence of logrolling because it occurred with low intensity.

The Committee of Constitution, Justice and Citizenship, the most crowded of the Senate, the most active Senator was Paulo Paim. The more intense relationship competed to Demóstenes Torres (DEM-GO) and Pedro Simon (PMDB-RS). As the Committee on Social Affairs, only one reciprocity was observed, between Romeu Tuma (PTB-SP) and Simon. However, this relation did not submit sufficient intensity that we might consider that the logrolling was or not practiced.

Intercommittee analysis showed us that we cannot affirm that the Senators practice exchange of votes between fixed commissions of the Senate. A fact noted was the low (or zero in some cases) movement in many committees of the Senate, preventing any analysis of trade support regarding these centers of parliamentary discussion.

We conclude that the logrolling was not observed within the limits imposed by our model for the Brazilian Federal Senate in the period on the $52^{\text {nd }}$ Legislature (2003-2006). The Senators, in this strict sense, behave random in opinions, there was no clear collusion between agents observed in the same (or different) party base (ideology), or geographic region of the country. One last finding point was the low congressional activity in a big number of Senate committees.

\section{Bibliography References}

BATAGELJ, V; DE NOOY, W; MRVAR, A. Explanatory social network analysis with Pajek. 1. ed. New York: Cambridge University Press, 2009. 334 p.

BERNHOLZ, P. (1973) "Logrolling, Arrow paradox and cyclical majorities." Public Choice, v.15, p. 87-95.

. (1978). On the stability of logrolling outcomes in stochastic games. Public Choice, v.33, n. 3, p. 65-82.

BLACK, D. The theory of committees and elections. 2. ed. Norwell: Kluwer Academic Publishing, 1998 [1958]. 512 p.

BRASIL. Congresso. Senado. Resolução no 93 de 1970. (2007). Dispões sobre o regimento interno do Senado Federal. Brasília, v. 1, p. 1-313.

BUCHANAN, J. M.; TULLOCK, G. (1990) The calculus of consent: logical foundations of constitutional democracy. 1.ed. Indianapolis: Liberty Fund., [1962]. 337 p. (The selected works of Gordon Tullock v. 2).

CALDARELLI, G. (2007). Scale-free networks: complex webs in nature and technology. 1. ed. New York: Oxford University Press. 309 p. 
CARRUBBA, C. J.; VOLDEN, C. (2000). "Coalitional politics and logrolling in legislative institutions.” American Journal of Political Science, Bloomington, v. 44, n. 2, p. 261-277.

COLEMAN, J. S. (1967). "The possibility of a social welfare function: reply." The American Economic Review, v. 57, n.5 p. 1311 - 1317.

CONDORCET, N. C. Essai sur l'application de l'analyse a la probabilite des decisions rendues a la pluralite des voix, 1. ed. Paris, 1785. $195 \mathrm{p}$.

ENELOW, J. M. (1997). Cycling and majority rule. In: MUELLER, D. C. (org.). Perspectives on public choice: a handbook. 1. ed. New York: Cambridge University Press, cap. 7, p. 149-162.

FIGUEIREDO, A. C.; LIMONGI, F. (1999). Executivo e legislativo na nova ordem constitucional. 1 ed. Rio de Janeiro: Editora FGV, 232 p.

. (2002). "Incentivos eleitorais, partidos e política orçamentária.” Dados, Rio de Janeiro, v.45, n.2, p. 303-344.

HARDIN, R. (1997). Economic theories of the state. In: MUELLER, D. C. (org.). Perspectives on public choice: a handbook. 1. ed. New York: Cambridge University Press, cap. 2, p. 21-35.

KOFORD, K. J. G. (1982). “Centralized vote-trading.” Public Choice, New York, v. 39, n.2 p. $245-268$.

MAY, K. O. A set of independent necessary and sufficient conditions for simple majority decisions. Econometrica, v. 20, n. 4, p. 680-684, 1952.

. A note on the complete independence of the conditions for simple majority decision. Econometrica, v. 21, p. 172-173, 1953.

MUELLER, D. C. (1997). “Constitutional public choice.” In: MUELLER, Dennis C. (org.). Perspectives on public choice: a handbook. 1. ed. New York: Cambridge University Press, cap. 6, p. 124-146 $768 \mathrm{p}$.

. (2009). "Public choice III." 9th ed. New York: Cambridge University Press,

OSTROM, E.; WALKER, J. (1997). "Neither markets nor states: linking transformation processesin collective action arenas." In: MUELLER, D. C. (org.). Perspectives on public choice: a handbook. 1. ed. New York: Cambridge University Press, cap. 1, p. 35-72.

PEREIRA, C.; MUELLER, B. (2002). Comportamento estratégico em presidencialismo de coalizão: as relações entre executivo e legislativo na elaboração do orçamento brasileiro. Dados, Rio de Janeiro, v. 45, n. 2, p. 265-301.

. (2003). "Partidos fracos na arena eleitoral e partidos fortes na arena legislativa: a conexão eleitoral no Brasil.” Dados, Rio de Janeiro, v. 46, n. 4, p. 735-771.

PEYTON YOUNG, H. (1997) “Group choice and individual judgements.” In: MUELLER, D. C. (org.). Perspectives on public choice: a handbook. 1. ed. New York: Cambridge University Press, cap. 9, p. 181-200

PLOTT, C. R. A notion of equilibrium and its possibility under majority rule. American Economic Review, v. 57, p. 787-806, 1967. 
SCHOFIELD, N. (1997). “Multiparty electoral politics.” In: MUELLER, D. C. (org.). Perspectives on public choice: a handbook. 1. ed. New York: Cambridge University Press, cap. 13, p. 271-295.

SCOTT, J. Social network analysis: a handbook. 2.ed. London: Sage Publications, 2009.

SHEPSLE, K. A.; WEINGAST, B. R. Structure-induced equilibrium and legislative choice. Public Choice, New York, v. 37, n.3 p. 503 - 519, 1981.

STRATMANN, T. Logrolling. In: MUELLER, D. C. (org.). Perspectives on public choice: a handbook. 1. ed. New York: Cambridge University Press, 1997. cap. 15, p. 322-341.

TIDEMAN, T. N. Voting and the revelation of preferences for public activities. In: MUELLER, D. C. (org.). Perspectives on public choice: a handbook. 1. ed. New York: Cambridge University Press, 1997. cap. 11, p. 226-244

TULLOCK, G. (1981). "Why so much stability?” Public Choice, New York, v. 37, n.2 p. $189-204$.

WIETING JR., H. L. (1966). Philosophical problems in majority rule and the logrolling solution. Ethics, Chicago, v. 76, n. 2, p. 85-101.

WOLF, F. (2008). "O comportamento dos deputados na Câmara Federal: uma abordagem de redes sociais.”123 f. Dissertação (Mestrado Acadêmico em Ciência Política) - Instituto de Ciência Política, Universidade de Brasília, Brasília.

Recebido em: 03 de maio de 2013

Aceito em : 24 de janeiro de 2014 